\title{
Independent Corporate Governance Organs Activities and Tax Avoidance Activities: Evidence from Indonesia
}

\author{
Oktavia \\ Faculty of Economics and Business, Universitas Kristen Krida Wacana, Jakarta \\ E-mail address: \\ oktavia@ukrida.ac.id
}

\begin{abstract}
This study aims to examine the effect of independent corporate governance organs activities (i.e. the level of busyness and political connections of independent corporate governance organs) on tax avoidance activities. By using a sample of manufacturing companies and panel data analysis, this study finds evidence that: (i) The busyness level of independent directors and audit committee have a positive effect on tax avoidance activities. This indicates that the more positions or jobs hold by independent directors and audit committees, thus their duties to monitor the company may be neglected and in turn they are unable to detect that the company is engaged in aggressive tax avoidance; (ii) Political connections of independent directors and audit committees have a positive effect on tax avoidance activities. This suggests that independent directors and audit committees can take advantage from their political connections to make a politics lobby that can reduce the corporate tax burden.
\end{abstract}

Keywords: Corporate governance, busyness, political connections, tax avoidance.

Abstrak: Penelitian ini bertujuan untuk menguji pengaruh aktivitas organ tata kelola perusahaan yang independen (yaitu tingkat kesibukan dan koneksi politik organ tata kelola perusahaan yang independen) terhadap aktivitas penghindaran pajak. Dengan menggunakan sampel perusahaan manufaktur dan analisis data panel, penelitian ini menemukan bukti bahwa: (i) Tingkat kesibukan direksi independen dan komite audit berpengaruh positif terhadap kegiatan penghindaran pajak. Hal ini menunjukkan bahwa semakin banyak posisi atau pekerjaan yang dijabat oleh direktur independen dan komite audit, maka tugas mereka untuk memantau perusahaan dapat terabaikan dan pada gilirannya mereka tidak dapat mendeteksi bahwa perusahaan tersebut melakukan tindakan penghindaran pajak yang agresif; (ii) Koneksi politik direktur independen dan komite audit berpengaruh positif terhadap aktivitas penghindaran pajak. Hal ini menunjukkan bahwa direktur independen dan komite audit dapat memanfaatkan koneksi politiknya untuk melakukan lobi politik yang dapat mengurangi beban pajak perusahaan.

Kata kunci: Tata kelola perusahaan, kesibukan, koneksi politik, penghindaran pajak. 


\section{INTRODUCTION}

Good and effective corporate governance can reduce a firm's management activities that are opportunistic and may harm shareholders. As a firm's corporate governance grows better and effective, monitoring the firm's management activities becomes more efficient. Research conducted by Raja et al. (2014) and Gunawan \& Situmorang (2016) found that the existence of audit committees in firms reduces opportunistic earnings management activities. The argument for this finding is that the existence of an audit committee may cause the firm's management feeling supervised inducing it to become more careful in carrying out its duties.

Furthermore, research conducted by Rajpal (2012) in India also found that firms that had busy independent directors tended to have higher absolute discretionary accruals than other firms. As absolute value of high discretionary accruals indicates a high practice of earnings management, these findings indicate that the busier independent directors become, the less time they have to monitor the firm's management activities, inducing the management to carry out more earnings management activities.

In addition to reducing opportunistic and aggressive earnings management practices, good and effective corporate governance can also reduce opportunistic and aggressive tax avoidance activities. Tax avoidance activitiesare basically done for opportunistic purposes (such as: rent diversion) or for efficient purposes (such as reducing the tax burden to increase shareholder's wealth). Opportunistic and aggressive tax avoidance activities can be detrimental to shareholders, because the firm will bear loss in the form of future tax sanctions which will further damage the firm's reputation. Furthermore, Hanlon (2005) also argued that a high level of tax avoidance may lead to low quality of earnings reported by firms. This may harm shareholders because the information contained in profits may mislead shareholders in making investment decisions. Therefore, the role of good and effective corporate governance is needed to prevent aggressive tax avoidance activities that harm shareholders.

This study re-examines the effect of corporate governance on tax avoidance activities. Several gaps (research gaps) exist between this study and previous research. First, previous research examined the effect of corporate governance on tax avoidance activities (Putri \& Diyanty, 2014; Midiastuty et al., 2016; Arismajayanti \& Jati, 2017; Waluyo, 2017; Widuri et al., 2019), corporate governance was measured by using the existence, amount, or proportion of corporate governance organs (which included: independent commissioners, independent directors, and audit committees) in the firms.However, this study measures corporate governance by using the activities of corporate governance organs (i.e.: the level of busyness and political connections of corporate governance organs) when examining the effect of corporate governance on tax avoidance activities. The corporate governance organs examined in this study included only corporate governance organs that were independent or came from outside the firm, namely: independent commissioners, independent directors, and audit committees. This is because those three organs are more independent than other corporate governance organs. The existence of an independent organ as a tool of corporate governance will likely improve effective monitoring in a firm, so that it reduces the firm's management activities that harm investors. However, if independent commissioners, independent directors, and audit committees are too busy, they may neglect their duties in 
monitoring the firm, and in turn may cause them to not realize that the firm's management is conducting aggrasive tax avoidance activities.

Second, research conducted by Rajpal (2012) in India did indeed measure corporate governance using the level of busyness of independent directors, but their research focused only on the level of busyness of independent directors. In addition, Rajpal (2012) linked the level of busyness of independent directors only to earnings management activities. Unlike their research, this study examines the effect of the level of busyness of independent commissioners, independent directors, and audit committees on tax avoidance activities. Third, research conducted by Apriliani \& Diyanty (2016) and Puspitasari \& Nugrahanti (2016) also measured corporate governance in terms of political connections held by corporate governance organs. However, their research examined the only relationship between political connections held by corporate governance organs and earnings management activities. Unlike the research by Apriliani \& Diyanty (2016) and Puspitasari \& Nugrahanti (2016), this study links the political connections of corporate governance organs to tax avoidance activities. Furthermore, several previous studies (Francis et al., 2012; Kim \& Zhang, 2013; Christensen et al., 2015) did indeed examine the effect of political connections on tax avoidance activities, but their research did not spefically examine the effect of political connections held by independent commissioners, independent directors, and audit committees. While the research conducted by Pranoto \& Widagdo (2016) did measure the political connection aspect of independent commissioners, however it did not consider the political connections held by independent directors or the audit committee. Fourth, the measurement of corporate governance using the level of busyness of corporate governance organs was first carried out by Cashman et al. (2012). However, their research only linked the level of busyness of corporate governance organs to the value of the firm, not to tax avoidance activities.

It is hoped that this research will provide several contributions. The first contribution is: this research is the first to examine the activities of corporate governance organs (as measured by the level of busyness and political connections of corporate governance organs) in relation to tax avoidance activities. Based on the literature survey conducted to date, research that study corporate governance measured in terms of independent corporate governance activityare relatively rare, especially when testing the relationship between corporate governance and corporate tax avoidance activities. As no research has been found that specifically links the activities of independent corporate governance organs to tax avoidance activities, this research accommodates this gap.

The second contribution is that this research is expected to provide input to the authorities who oversee the capital market in Indonesia regarding the importance of monitoring the activities of independent corporate governance organs (which includes "level of busyness" and "political connections" of independent commissioners, independent directors, and audit committees). If an independent board member of a corporate governance organ occupies several positions in other firms / institutions, he may well neglect his duty to monitor the firm. Therefore, Indonesia's capital market supervisory authorityshould consider establishing a policy on the number of jobs or positions that are allowed to be held by an independent member of a corporate governance organ, so that corporate governance organs be more effective in monitoring the activities of the firm. With regard to political connections, this research is expected to provide input to capital market supervisory 
authorities on the question whether it is necessary or not to set rules for independent members of corporate governance organs to be allowed or not allowed to hold political connections.

\section{THEORETICAL REVIEW}

Agency Theory. Jensen \& Meckling (1976) state that agency relations constitute contracts between one or more owners (principals) and managers (agents) who work for the benefit of the owner (principal), including delegating power to the manager to take decisions in the interest of the owner (principal). According to Jensen \& Meckling (1976), the agency relationship will experience conflict (agency conflict) if the manager as an agent tries to maximize his personal prosperity and acts for his own interests. In order to maximize his personal prosperity, managers may utilize asymmetric information (information gap between managers and owners) to practice opportunistic tax avoidance (such as: for rent diversion purposes), even though they are expected to carry out efficient tax avoidance activities (such as: reduce tax burden to increase shareholder wealth).

Tax avoidance practices that are opportunistic / aggressive may lead to low earnings quality (Hanlon, 2005), reduce financial statement transparency and increase information asymmetry (Balakhrisnan et al., 2011). With increasing asymmetric information, tax avoidance activities provide increasingly opportunities to managers to conduct rent diversions, hide bad news, and mislead investors (Kim et al., 2011). This certainly can cause investors to make wrong investment decisions. Therefore, to ensure that managers carry out contracts in accordance with the owners' interests, agency costs arise, namely monitoring costs and bonding costs, in order to overcome the agency conflict (Jensen and Meckling, 1976). This monitoring cost is realized in the form of good and effective corporate governance to monitor the firm's management and prevent actions that harm shareholders.

The Effect of Busyness Levels of Independent Corporate Governance Organs on Tax Avoidance Activities. According to Hanlon (2005), the greater the difference between taxable income and accounting income, the lower the quality of the firm's earnings. As the difference between taxable income and accounting income (book-tax difference) is one of the proxies of tax avoidance activities, the findings of Hanlon (2005) research indicate that firms with high tax avoidance have lower earnings quality than firms with low tax avoidance. If investors do not realize that a high level of tax avoidance can lead to low earnings quality, investors will experience errors in assessing earnings components of firms that have a high level of tax avoidance, which in turn can cause investors to make wrong investment decisions.

Good and effective corporate governance is expected to reduce aggressive tax avoidance activities that may harm investors. Previous research studied the link between corporate governance and tax avoidance activities (Putri \& Diyanty, 2014; Midiastuty et al., 2016; Arismajayanti \& Jati, 2017; Waluyo, 2017; Widuri et al. 2019). However, their research only measured corporate governance in terms of the existence, amount, or proportion of an independent corporate governance organ. This study measures corporate governance indifferent ways, namely in terms of the level of busyness and political connections of an independent corporate governance organ. 
The importance of measuring corporate governance in terms of the level of busyness of independent corporate governance organs (including: independent commissioners, independentdirectors, and audit committees) is because the busyness of an independent governance organ can be an obstacle for government authorities (especially capital market supervisors) in realizing good corporate governance and a good protection mechanism for investors in the capital market. If independent commissioners, independent directors, and audit committees engage in a lot of work or hold multiple positions outside the firm, their duty to monitor the activities of the firm become neglected, so that in turn they can not detect aggressive tax avoidance activities. Based on the above arguments, the following hypotheses are formulated:

H1a: The level of busyness of an independent commissioner has a positive effect on the level of tax avoidance

$H 1 b$ : The level of busyness of an independent director has a positive effect on the level of tax avoidance

H1c: The level of busyness of an audit committee has a positive effect on the level of tax avoidance

The Effect of Political Connections of Independent Corporate Governance Organs on Tax Avoidance Activities. Measuring corporate governance in terms of political connections held by independent corporate governance organs is also important. Political connections may have positive effects and may also negatively affect tax avoidance activities (Richardson et al., 2016; Pranoto \& Widagdo, 2016). According to Richardson et al. (2016), Chinese firms that have political connections can lobby the government, especially tax authorities, in order to avoid tax audits, request a reduction in tax fines, or take other tax avoidance actions. This shows that firmshaving political connections tend to have higher aggressive tax avoidance compared to firms that do not have political connections. According to Pranoto \& Widagdo (2016), if political connections increase tax aggressiveness, the effect of political connections on tax avoidance activities is known as "political favoritism effect".

On the other hand, Richardson et al. (2016) also argued that political connections can negatively affect tax avoidance activities, because the Chinese government provides incentives in the form of awards to the largest taxpayer, thus encouraging firms to contribute more in fulfilling their tax payment obligations. In addition, the public also show positive response to such firms. If political connections reduce tax aggressiveness of a firm, then the effect of political connections on tax avoidance activities is known as the "bureaucratic incentive effect" (Pranoto \& Widagdo, 2016).

Consistent with the arguments of Richardson et al. (2016) and Pranoto \& Widagdo (2016), this study also argues that political connections may have two effects (positive or negative). On the one hand, an independent and politically connected corporate governance organ may lobby tax authorities if the firm being monitored is facing a tax audit or tax trial. This causes the firm management to be more aggressive in carrying out tax avoidance activities. On the other hand, corporate governance organs that are independent and have political connections will be more careful in carrying out such activities because they realize that they are in the public spotlight. This certainly motivates them to act more prudently, including to refrain from tax avoidance activities that are too aggressiveas wells as inflict 
losses to state revenues and investors. Based on the above arguments, the following hypotheses are formulated:

H2a: Political connections of independent commissioners affect the level of tax avoidance

H2b: Political connections of independent directors affect the level of tax avoidance

H2c: Political connections of audit committees affect the level of tax avoidance

\section{METHOD}

Research Data and Samples. Annual reports and financial statements data were collected from the Thomson Reuters-Datastream Pro data center available at the Faculty of Economic and Business Data Center (PDEB), Universitas Indonesia. The data used for this researchare derived from the time periods 2014-2016. The population of this study are non-financial companies listed on the Indonesia Stock Exchange (IDX), while the sample selection of firms was conducted using a purposive sampling method, namely the selection of samples with several certain criteria. Following are the sample criteria used: (1) The firm was engaged in the manufacturing industry sector. (2) The firm calculated taxable income normally based on net income basis and used a normal corporate income tax rate. Firms that calculated their taxable income basedon gross revenue or firms subjected to special income tax rates were excluded from the sample of this study. (3) Of the examined time period, the firm employed an independent director. (4) The complete data needed for this research are available.

Table 1 presents the sample selection process in this study. Table 1 shows that this study has 317 firm-years final observations. This number reflects the number of unbalanced observation panel data. In this study, outliers with a $1 \%$ criterion of the upper and lower limits of the percentile were overcome by performing the winsorizing procedure. 
Table 1. Sample Selection Process

\begin{tabular}{|c|c|}
\hline Number of manufacturing firms listed on the IDX & 143 \\
\hline $\begin{array}{l}\text { Firms that calculated their taxable income based on gross revenue or firms that were } \\
\text { subject to special income tax rates }\end{array}$ & (4) \\
\hline $\begin{array}{l}\text { Number of firmsthat for } 3 \text { consecutive years (from } 2014 \text { until 2016) did not employ } \\
\text { independent directors }\end{array}$ & $(25)$ \\
\hline Number of firms used as samples & 114 \\
\hline Number of observations (114 firms x 3 years)- balanced panel & 342 \\
\hline Amount of incomplete data during 2014 & $(17)$ \\
\hline Amount of incomplete data during 2015 & (3) \\
\hline Amount of incomplete data during 2016 & $(5)$ \\
\hline Number of final observations-unbalanced panel & 317 \\
\hline
\end{tabular}

Source: (data processed, 2019)

Research Model. Equation (1) is used to examine the relationship between the activities of independent corporate governance organs (i.e.: the level of busyness and political connections of corporate governance organs) and tax avoidance activities.

$$
\begin{aligned}
\text { ABS_BTD }_{\text {it }}= & \alpha_{0}+\alpha_{1} \text { BUSYCOM }_{\mathrm{it}}+\alpha_{2} \text { BUSYDIR }_{\mathrm{it}}+\alpha_{3} \text { BUSYCOMDIT }_{\mathrm{it}}+\alpha_{4} \text { POLCOM }_{\mathrm{it}}+ \\
& \alpha_{5} \text { POLDIR }_{\mathrm{it}}+\alpha_{6} \text { POLCOMDIT }_{\mathrm{it}}+\alpha_{7} \text { SIZE }_{\mathrm{it}}+\alpha_{8} \text { ROA }_{\mathrm{it}}+\alpha_{9} \mathrm{DTA}_{\mathrm{it}}+ \\
& \alpha_{10} \mathrm{CAPINT}_{\mathrm{it}}+\varepsilon_{\mathrm{it}}
\end{aligned}
$$

H1a: $\alpha_{1}>0$; H1b: $\alpha_{2}>0$; H1c: $\alpha_{3}>0$

H2a: $\alpha_{4} \neq 0 ; \mathrm{H} 2 \mathrm{~b}: \alpha_{5} \neq 0$; H2c: $\alpha_{6} \neq 0$

Description:

ABS_BTD

BUSYCOM

BUSYDIR

BUSYCOMDIT

$=$ The level of tax avoidance (measured by the absolute value of Book Tax Difference)

$\begin{array}{ll}\text { POLDIR } & \text { Political connections of independent commis } \\ \text { POLCOI } & \text { Political connections of independent directors }\end{array}$

POLCOMDIT = Political connections ofaudit committee

SIZE

$=$ logaritma natural of total asset

ROA

$=$ Return on asset

DTA

$=$ Debt to total asset ratio

CAPINT

$=$ Capital Intensity

\section{Operationalization of Research Variables}

Tax Avoidance Rate (ABS_BTD). The level of tax avoidance is measured using the absolute value of BTD (Book-Tax Difference). We use the absolute BTD measurement used by 
Hanlon (2005), Tang \& Firth (2012), Hanlon et al. (2012), and Oktavia et al. (2019). The arguments of Hanlon (2005) and Hanlon et al. (2012) who used the absolute value of BTD in their research was that the BTD which has a large value, regardless of its direction, provides an indication of low earnings quality. Tang and Firth (2012) also used the absolute value of abnormal BTD in their research on the grounds that abnormal BTD which has a large and positive value (large positive abnormal BTD) is the result of earnings management practices that increase accounting income (upward earnings management) and aggressive tax reporting. Whereas abnormal large and negative BTD values (large negative abnormal BTD) are the result of earnings management practices that reduce accounting earnings (downward earnings management) and fiscal income smoothing practices.

BTD measurement is used because it can capture earnings management activities and tax avoidance activities carried out by firms (Hanlon, 2005; Tang \& Firth, 2012; Hanlon et al., 2012). BTD is measured by using the difference between accounting income and taxable income. Fiscal income is calculated by dividing the current tax expense with the statutory tax rate. This research also takes into account the impact of tax incentives stipulated by Government Regulation of the Republic of Indonesia Number 81 of 2007 and Government Regulation of the Republic of Indonesia Number 77 of 2013 about Decreasing Income Tax Rates for Domestic Taxpayers in the Form of Public Listed Companies. Thus, for theIndonesian firmsthat utilize these tax incentives, the tariff used is the applicable income tax rate after deducting a 5\% reduction in tariffs.

Level of Busyness of Independent Corporate Governance Organs. The corporate governance organs tested in this study consisted of independent commissioners, independent directors, and audit committees. All three were chosen because they constitute corporate governance organs and come from independent parties (from outside the firm). Thus, three variables of level of busyness of the corporate governance organs are examined in this study, namely: the level of busyness of independent commissioners (BUSYCOM), the level of busyness of independent directors (BUSYDIR), and the level of busyness of the audit committees (BUSYCOMDIT). BUSYCOM is measured using the average number of jobs or positions outsiode the company held by the independent commissioners, BUSYDIR is measured using the average number of jobs or positions outside the company held by the independent directors, and BUSYCOMDIT is measured through the average number of jobs or positions outside the company held by the audit committee.

Political Connection of Independent Corporate Governance Organs. Three variables of political connections are examined in this study, namely: political connections from independent commissioners (POLCOM), political connections from independent directors (POLDIR), and political connections from the audit committee (POLCOMDIT). The political connection in this study were measured using dummy variables. The value of 1 for independent corporate governance organs holding political connections, and 0 for others. For example, in a firm having three independent commissioners and one of the three has a political connection, the dummy number given is 1 . Political connections in this study includes: (i) Holding a position in Government; and (ii) Engages in a political party.

Control Variables. The control variables used in this study are as follows:

a. Firm size (SIZE): This variable is measured using the natural logarithm of total assets. 
b. Profitability (ROA): The profitability variable in this study is measured using the Return on Assets (ROA) ratio, which was calculated using the ratio of net income to total assets at the end of the year.

c. Leverage (DTA): The leverage variable in this study is measured using the ratio of total debt to total assets at the end of the year.

d. Capital intensity (CAPINT): This variable is calculated using the ratio of fixed assets after deducting accumulated depreciation from the total assets of the previous year.

Sensitivity Analysis and Additional Analysis. To conduct a sensitivity analysis, this study changes the ABS_BTD variable with the ETR (effective tax rate). In addition, this study also carries out additional analysis by comparing the average tax avoidance rate of firms that employed independent directors and firms that did not employ independent directors. Table 1 depicts 25 manufacturing firms listed on the IDX did not employ independent directors during the time periods used for this study. Therefore an additional analysis is conducted to find out whether the average tax avoidance rate of firms that did not employ independent directors was higher than the average level of tax avoidance at firms that employed independent directors.

\section{RESULT AND DISCUSSION}

Descriptive statistics. As presented inTable 2, the ABS_BTD variable is measured using natural logarithms of the absolute value of the difference in taxable income and accounting income, showing an average value of 24.2461 and a standard deviation value of 2.0275, this further shows a fairly high variation in the book tax difference. As also can be seen, the SIZE variable has an average value of 28.2999 with a standard deviation of 1.5234 , ROA has an average value of 0.0521 with a standard deviation of 0.1040 , DTA has an average value of 0.5302 with a standard deviation of 0.3037 , and CAPINT has an average value of 0.8675 with a standard deviation of 0.6133 . A positive average ROA value indicates that on average the sampled firms were in a profit-making condition.

As is shown by the data presented in Table 2, the number of firms that employed independent commissioners with high levels of busyness is $55.21 \%$ of the total observations, while the number of firms that employed independent directors and audit committees with high levels of busyness is $12.30 \%$ and $30.28 \%$ respectively. In addition as is depicted, most of the samples of this study are firms whose corporate governance organs did not hold political connections. 
Table 2. Descriptive Statistics

\begin{tabular}{|c|c|c|c|c|c|c|}
\hline Variable & $\mathbf{N}$ & Mean & Median & Minimum & Maximum & Std. Dev. \\
\hline ABS_BTD & 317 & 24.2461 & 24.2355 & 16.4008 & 29.3338 & 2.0275 \\
\hline SIZE & 317 & 28.2999 & 28.2999 & 25.2305 & 33.1988 & 1.5234 \\
\hline ROA & 317 & 0.0521 & 0.0407 & -0.2959 & 0.5803 & 0.1040 \\
\hline DTA & 317 & 0.5302 & 0.5207 & 0.0610 & 2.0558 & 0.3037 \\
\hline CAPINT & 317 & 0.8675 & 0.7108 & 0.1066 & 3.7633 & 0.6133 \\
\hline & & \multicolumn{2}{|c|}{ Dummy Proportion = 1} & & \multicolumn{2}{|c|}{ Dummy Proportion = 0} \\
\hline & & $\mathbf{N}$ & $\%$ & & $\mathbf{N}$ & $\%$ \\
\hline BUSYCOM & & 175 & $55.21 \%$ & & 142 & $44.79 \%$ \\
\hline BUSYDIR & & 39 & $12.30 \%$ & & 278 & $87.70 \%$ \\
\hline BUSYCOMDIT & & 96 & $30.28 \%$ & & 221 & $69.72 \%$ \\
\hline POLCOM & & 94 & $29.65 \%$ & & 223 & $70.35 \%$ \\
\hline POLDIR & & 9 & $2.84 \%$ & & 308 & $97.16 \%$ \\
\hline POLCOMDIT & & 93 & $29.34 \%$ & & 224 & $70.66 \%$ \\
\hline
\end{tabular}

Source: (data processed, 2019)

Correlation Matrix. Table 3 shows the correlation between variables in this study. As is shown, the BUSYCOM variable has a significant positive correlation with the ABS_BTD variable, which indicates that the higher the level of busyness of the independent commissioner, the higher the level of tax avoidance carried out by the firm. The BUSYCOMDIT variable has a significant positive correlation with the ABS_BTD variable, which indicates that the higher the level of busyness of the audit committee, the higher the level of tax avoidance carried out by the firm. In addition, it is also shown that the POLCOM and POLCOMDIT variables are significantly positively correlated with the ABS_BTD variable. These results indicate that political connections held by independent commissioners and audit committees may cause corporate tax avoidance activities become more aggressive.

As is also presented in Table 3, the ROA control variables are not significantly correlated with the ABS_BTD variable. While the control variables SIZE, DTA, and CAPINT have significant positive correlations with the ABS_BTD variable. This shows that the larger the size of the firm, the higher the level of corporate debt, as well as the higher the firm's capital intensity, the higher the level of tax avoidance carried out by the firm. In addition, Table 3 also shows that the correlation value between the independent variables in this study does not exceed the value of 0.8 . Thus, it can be concluded that the model in this study does not experience significant multicollinearity.

Table 3. Correlation Matrix

\begin{tabular}{|c|c|c|c|c|c|c|c|c|c|c|c|}
\hline Variable & (1) & (2) & (3) & (4) & (5) & (6) & (7) & (8) & (9) & (10) & (11) \\
\hline (1) & 1.000 & & & & & & & & & & \\
\hline (2) & $* 0.104$ & 1.000 & & & & & & & & & \\
\hline (3) & 0.045 & $* 0.105$ & 1.000 & & & & & & & & \\
\hline (4) & $* * * 0.178$ & $* * * 0.442$ & $* * 0.129$ & 1.000 & & & & & & & \\
\hline (5) & $* * * 0.223$ & 0.085 & $* * 0.114$ & $* * * 0.173$ & 1.000 & & & & & & \\
\hline (6) & 0.017 & $* *-0.113$ & -0.064 & 0.011 & 0.014 & 1.000 & & & & & \\
\hline
\end{tabular}




\begin{tabular}{|c|c|c|c|c|c|c|c|c|c|c|c|}
\hline (7) & $* * * 0.272$ & $* * 0.120$ & $* * 0.117$ & $* * * 0.223$ & $* * * 0.734$ & -0.026 & 1.000 & & & & \\
\hline (8) & $* * * 0.712$ & $* * 0.125$ & 0.069 & $* * * 0.226$ & $* * * 0.282$ & -0.046 & $* * * 0.382$ & 1.000 & & & \\
\hline (9) & -0.059 & 0.065 & -0.072 & $* * * 0.209$ & 0.091 & -0.025 & $* 0.101$ & 0.060 & 1.000 & & \\
\hline (10) & $* 0.107$ & -0.089 & 0.043 & $* * *-0.149$ & 0.082 & 0.051 & -0.014 & 0.008 & $* * *-0.278$ & 1.000 & \\
\hline (11) & $* 0.097$ & -0.0813 & -0.040 & -0.010 & 0.036 & 0.002 & 0.091 & 0.053 & $* * *-0.182$ & $* * * 0.420$ & 1.000 \\
\hline $\begin{array}{l}\text { BS_B } \\
\text { APINT }\end{array}$ & USYCO & (2); BUSY & R(3); B & YCOMDI & $\overline{\mathrm{OLCOM}}$ & & (6); POI & & ); SIZE(8); & ROA(9); D & $\mathrm{A}(10) ;$ \\
\hline
\end{tabular}

Source: (data processed, 2019)

\section{Regression Results}

The Effect of Busyness Levels of Independent Corporate Governance Organs on Tax Avoidance Activities

Table 4 shows that the estimation model has an R-square value of $42.61 \%$. It means that the independent variable is able to explain the dependent variable as much as only $42.61 \%$, while the rest is affected by other variables. The estimation model also has an Fstat value with a significant p-value at a $10 \%$ significance level, which means that all independent variables in the model are statistically significant to effectthe dependent variable. Furthermore, Table 4 shows that the BUSYDIR and BUSYCOMDIT variables have positive and significant coefficients. These results indicate that the level of busyness of independent directors and level of busyness of the audit committees have a positive effect on the level of tax avoidance. That is, the busier the independent director, the higher the level of tax avoidance carried out by the firm. The busier the audit committee, the higher the level of tax avoidance carried out by the firm. In accordance with the arguments formed in this study, the busyness of an independent corporate governance organ can be an obstacle to the realization of a good corporate governance mechanism.

As is also depicted in Table 4, the BUSYCOM variable has an insignificant coefficient. This indicates that there is not enough evidence to conclude that the level of busyness of independent commissioners affects the level of tax avoidance. Possibly because independent commissioners do not interact directly with the company's operation, so their level of busynessdo not affect the level of tax avoidance activities carried out by the firm. Based on the above findings, it can be concluded that $\mathrm{H} 1 \mathrm{~b}$ and $\mathrm{H} 1 \mathrm{c}$ hypotheses of this study are accepted, while the H1a hypothesis is not accepted.

Table 4 also indicates that only SIZE and CAPINT control variables have significant coefficients. While the coefficients of the ROA and DTA variables are insignificant. The non-effect of the debt level on tax avoidance rate is most likely due to exception and limitation on the amount of interest expense on debt that can be recognized as deductible expense. These exceptions and limitations cause that not all interest expense on debt can be recognized as a deduction from taxable income. As a result, the use of debt cannot replace the role of tax avoidance activities in an effort to minimize corporate tax burden. 
Table 4. Regression Results - Equation (1)

\begin{tabular}{|c|c|c|c|c|}
\hline \multicolumn{5}{|c|}{ 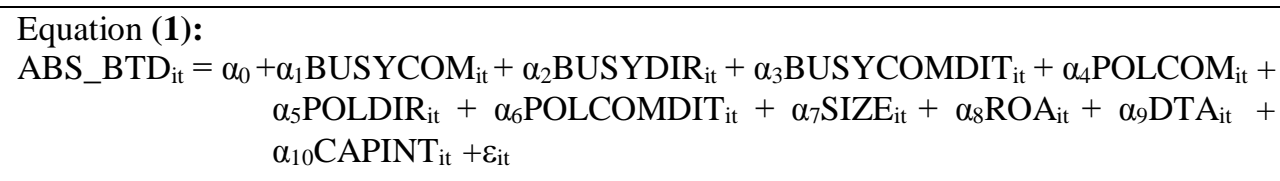 } \\
\hline Variable & Predicted Sign & Coefficient & t-statistic & Sig. \\
\hline Intercept & $?$ & 24.1994 & 32.53 & $* * * 0.0000$ \\
\hline BUSYCOM & + & -0.3643 & -1.01 & 0.1560 \\
\hline BUSYDIR & + & 0.9030 & 1.53 & $* 0.0640$ \\
\hline BUSYCOMDIT & + & 0.4221 & 1.35 & $* 0.0895$ \\
\hline POLCOM & + & 0.2015 & 0.76 & 0.2245 \\
\hline POLDIR & + & 0.9253 & 1.78 & $* * 0.0385$ \\
\hline POLCOMDIT & + & 0.2124 & 1.40 & $* 0.0820$ \\
\hline SIZE & $+/-$ & 0.8729 & 2.06 & $* * 0.0210$ \\
\hline ROA & $+/-$ & 1.8172 & 0.77 & 0.2210 \\
\hline DTA & $+/-$ & 0.6701 & 0.52 & 0.3010 \\
\hline CAPINT & $+/-$ & -0.5358 & -1.42 & $* 0.0790$ \\
\hline R-Square & & & $42.61 \%$ & \\
\hline F-statistic & & & $* 0.0780$ & \\
\hline $\mathrm{N}$ & & & 317 & \\
\hline
\end{tabular}

The Effect of Political Connections of Independent Corporate Governance Organs on Tax Avoidance Activities. Table 4 shows that the POLDIR and POLCOMDIT variables have positive and significant coefficients. These results indicate that political connections from independent directors and political connections from the audit committee have a positive and significant effect on the level of tax avoidance. This means that political connections held by independent directors as well as held by audit committees can cause tax avoidance activities to become more aggressive. This finding supports the view of "political favoritism effect". Furthermore, as can be seen in Table 4, the POLCOM variable has insignificant coefficients. This shows that the political connections held by independent commissioners did not cause tax avoidance activities to be more aggressive. These results indicate that independent commissioners did not take advantage of their political connections to reduce corporate tax burden.Although the board of commissioners does not interact directly with the company's operations, but they have the main duty of monitoring and providing suggestion to the board of director. Independent commissioners will always be professional in carrying out their duties, so that their political connections could not be utilized by the firm to lobby the government (specifically in reducing the firm's corporate tax burden). Based on the above findings, it can be concluded that the $\mathrm{H} 2 \mathrm{~b}$ and $\mathrm{H} 2 \mathrm{c}$ hypotheses are accepted, while the H2a hypothesis is not accepted. 


\section{Sensitivity Analysis and Additional Analysis}

Sensitivity Analysis. Table 5 represents the results of the sensitivity analysis in this study where the ABS_BTD variable is replaced by ETR (Effective Tax Rate). It is shown that the coefficients of BUSYDIR and BUSYCOMDIT have a negative and significant value. These results indicate that the level of busyness of the independent director and the level of busyness of the audit committee have a negative effect on ETR. That is, the higher the level ofindependent director busyness, the lower the effective tax rate of the firm. The higher the level ofaudit committee busyness, the lower the effective tax rate of the firm. This result is consistent with the results of the main tests which show that the level of busyness of the independent director and the level of busyness of the audit committee may increase corporate tax avoidance activities. Moreover, Table 5 shows that BUSYCOM does not have a significant coefficient, which is consistent with the results of the main tests in this study.

Table 5 also shows that the POLDIR and POLCOMDIT variables have negative and significant coefficients. These results indicate that political connections from independent directors and political connections from the audit committee have a negative effect on ETR. This means that political connections held by independent directors and audit committees may cause the firm's effective tax rate to be lower. These results are consistent with the main test results and further strengthen the evidence that supports the validity of $\mathrm{H} 2 \mathrm{~b}$ and $\mathrm{H} 2 \mathrm{c}$ hypothesis in this study. In addition, it was also found that POLCOM has insignificant coefficients. This result is consistent with the main test results in this study.

Table 5. Sensitivity Analysis - ABS_BTD replaced by ETR

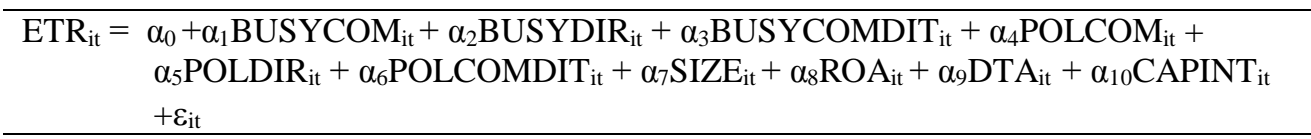

\begin{tabular}{|c|c|c|c|c|}
\hline Variable & Predicted Sign & Coefficient & t-statistic & Sig. \\
\hline Intercept & $?$ & 0.3350 & 1.74 & $* * 0.0420$ \\
\hline BUSYCOM & - & 0.0369 & 0.37 & 0.3575 \\
\hline BUSYDIR & - & -0.1040 & -1.48 & $* 0.0710$ \\
\hline BUSYCOMDIT & - & -0.0922 & -1.85 & $* * 0.0320$ \\
\hline POLCOM & - & 0.0702 & 0.81 & 0.2110 \\
\hline POLDIR & - & -0.0680 & -1.74 & $* * 0.0425$ \\
\hline POLCOMDIT & - & -0.0776 & -1.30 & $* 0.0990$ \\
\hline SIZE & $+/-$ & -0.1615 & -1.51 & $* 0.0670$ \\
\hline $\mathrm{ROA}$ & $+/-$ & -0.5534 & -1.45 & $* 0.0755$ \\
\hline DTA & $+/-$ & -0.0353 & -0.15 & 0.4415 \\
\hline CAPINT & $+/-$ & -0.0110 & -0.06 & 0.4750 \\
\hline Adjusted R-Square & & \multicolumn{3}{|c|}{$15.85 \%$} \\
\hline F-statistic & & \multicolumn{3}{|c|}{$* * 0.0373$} \\
\hline $\mathrm{N}$ & & \multicolumn{3}{|c|}{232} \\
\hline
\end{tabular}


Additional Analysis. Table 6 represents the average tax avoidance rates of manufacturing firms that employed independent directors and the average tax avoidance level of manufacturing firms that did not employ independent directors for 3 consecutive years. Tax avoidance is measured using ABS_BTD and ETR. From the size of ABS_BTD, it is indicated that the average ABS_BTD of firms that employed independent directors $(24,1413)$ is lower than the average ABS_BTD of firms that did not employ independent directors $(24,2461)$. This shows that the level of tax avoidance in firms that did not employ independent directors is higher than firms that employed independent directors. This provides initial indication that the existence of an independent director is very important to reduce aggressive tax avoidance activities.

Table 6 also depicts that the average effective tax rate (ETR) of firms that employed independent directors $(28.33 \%)$ is higher than the average effective tax rate (ETR) of firms that did not employ independent directors $(23,17 \%)$. This reinforces the evidence that the level of tax avoidance in firms that did not employ independent directors is higher than firms that employed independent directors. In firms that did not employ independent directors, the firm's effective tax rate was lower than the normal corporate income tax rate in Indonesia, namely: $25 \%$.

Table 6. Comparison of Average Tax Avoidance Rates:

Employed an Independent Director versus Did Not Employ an Independent Director

\begin{tabular}{ccc}
\hline Tax Avoidance Measures & $\begin{array}{c}\text { Firm employed an } \\
\text { independent director }\end{array}$ & $\begin{array}{c}\text { Firm did not employ an } \\
\text { independent director }\end{array}$ \\
\hline ABS_BTD average & 24.1413 & 24.2461 \\
ETR average & $28.33 \%$ & $23.17 \%$ \\
\hline
\end{tabular}

Source: (data processed, 2019)

\section{CONCLUSION}

Based on the results of testing the effect of the level of busyness of independent corporate governance organs on level of corporate tax avoidance, it can be concluded that the level of busyness of independent directors and level of busyness of audit committees havepositive effects on the level of corporate tax avoidance. The higher the level of busyness of independent directors and audit committees, the higher the level of tax avoidance are carried out by the firms. These results indicate that when independent directors and audit committees hold multiple positions or jobs, their duties as independent directors and audit committees to monitor the firm can be neglected, which in turn may cause the firm's management engage in more aggressive tax avoidance activities as the management find out that busy independent directors and audit committees do not have time to monitor the firm's activities.

The results of testing the effect of political connections of independent corporate governance organs onthe level of corporate tax avoidance also indicate that political connections held by independent directors and audit committees have a positive effect on the level of tax avoidance. This result supports the "political favoritism effect" which says 
that firms that have political connections tend to have a more aggressive level of tax avoidance compared to firms that do not have political connections (Richardson et al., 2016). Independent directors and audit committees can take advantage of their political connectionsby lobbying to reduce the firm's corporate tax burden.

This study also finds that the level of busyness and political connections of independent commissioners did not affect the level of tax avoidance carried out by the firm. This is because the independent commissioners do not interact directly with the company's operation. Whatever the level of the independent commissioner busyness, they will also miss information about the tax planning activities carried out by the firm if they do not interact directly with the company's operation. As a result, the busyness level of independent commissioner does not have impact on company's tax avoidance activities. In addition, independent commissioners also did not take advantage of their political connections to reduce the corporate tax burden. Independent commissioners were able to work well and remained professional, so that the political connections they held could not beused by the firm to lobby tax authority for reducing the firm's corporate tax burden.

The results of this study are important for the Indonesian capital market supervisory authorities. This study proves that the level of busyness of an independent corporate governance organ has positive effects on the level of tax avoidance. The implication of these results is that the capital market supervisory authority should determine how many jobs or positions that independent corporate governance organ may hold outside the firm. This is important as it helps to achieve good corporate governance in Indonesia and as a form of better protection for investors in the capital market.

The results of this study may also provide input to Indonesian tax authorities. The results show that firms can use the political connections of their independent corporate governance organs for lobbying tax authority to reduce the firm's corporate tax burden. This certainly will harm state revenues in the taxation sector. Other additional input to Indonesian capital market authorities is that independent corporate governance organs may use their political connections in aggressive tax avoidance practices.

This research has several limitations. First, this study only usesfirms engaged in the manufacturing sector as research samples. Further research can expand the testing using firms engaged in other industrial sectors as research samples. Second, this study only measures the activities of corporate governance organs that are independent in terms of the level of busyness outside the firm and in terms of their political connections. Further research could measure the activities of independent corporate governance organs in terms of the length of time a person serves as an independent corporate governance organ, because it is suspected that the longer a person serves as an independent corporate governance organ, the person's independence may reduce. Third, this studyconducted tests using a sample of Indonesian firms only. Future research can expand testing using samples of firms of ASEAN member countries.

\section{REFERENCES}

Apriliani, Adiarti \& Vera Diyanty. (2016). The impact of family ownership and political connections on earnings management. Prosiding Simposium Nasional Akuntansi (SNA) XIX, Universitas Negeri Lampung. 
Arismajayanti, Ni Putu Ayu, \& I Ketut Jati. (2017). Influence of audit committee competence, audit committee independence, independent commissioner and leverage on tax aggressiveness. Journal of Auditing, Finance, and Forensic Accounting, 5 (2), $109-119$.

Balakrishnan, Karthik, Jennifer Blouin, \& Wayne Guay. (2019). Tax aggressiveness and corporate transparency. The Accounting Review, 94 (1), 45 - 69.

Cashman, George D., Gillan, Stuart L., \& Jun, Chulhee. (2012). Going overboard? On busy directors and firm value. Journal of Banking \& Finance, 36 (12), 3248-3259.

Christensen, Dane M., Dan S. Dhaliwal, Steven Boivie, \& Scott D. Graffin. (2015). Top management conservatism and corporate risk strategy: evidence from managers' personal political orientation and corporate tax avoidance. Strategic Management Journal, 36 (12), 1918-1938.

Gunawan, \& Elona Meita Situmorang. (2016). Pengaruh dewan komisaris, kepemilikan manajerial dan komite audit terhadap manajemen laba pada perusahaan BUMN di bursa efek Indonesia periode tahun 2011 - 2015. Jurnal Ekonomi, Manajemen, dan Perbankan, 2 (2), 55 - 62.

Hanlon, M. (2005). The persistence and pricing of earnings, accruals, and cash flows when firms have large book tax differences. The Accounting Review, 80 (1), 137-166.

Hanlon, M, Gopal V. Krishnan, \& Lillian F. Mills. (2012). Audit fees and book-tax difference. Journal of the American Taxation Association, 34 (1), 55 - 86.

Jensen, Michael C. \& W.H. Meckling. (1976). Theory of The Firm: Managerial Behavior, Agency Costs and Ownership Structure. Journal of Financial Economics, 3 (4), 305360.

Kim, Jeong-Bon, Yinghua Li, \& Liandong Zhang. (2011). Corporate tax avoidance and stock price crash risk: Firm-level analysis. Journal of Financial Economics, 100 (3), $639-662$.

Kim, Chansog (Francis), \& Liandong Zhang. (2013). Corporate Political Connections and Tax Aggressiveness. Contemporary Accounting Research, 33 (1), 78-114.

Midiastuty, Pratana Puspa, Eddy Suranta, Rini Indriani, \& Sarry Irawati Putri. (2016). Pengaruh kepemilikan pengendali dan corporate governance terhadap tindakan pajak agresif. Simposium Nasional Akuntansi (SNA) XIX, Universitas Negeri Lampung.

Oktavia, Sylvia Veronica Siregar, Ratna Wardhani, \& Ning Rahayu. (2019). The role of country tax environment on the relationship between financial derivatives and tax avoidance. Asian Journal of Accounting Research, 4 (1), 70 - 94.

Pranoto, Bayu Agung, \& Ari Kuncoro Widagdo. (2016). Pengaruh koneksi politik dan corporate governance terhadap tax aggressiveness. The $3^{\text {rd }}$ Call for Syariah Paper, FEB UMS.

Puspitasari, Andriana, \& Yeterina W. Nugrahanti. (2016). Pengaruh Hubungan Politik, Ukuran KAP, dan Audit Tenure Terhadap Manajemen Laba Riil. Jurnal Akuntansi dan Keuangan, 18 (1),27-43.

Putri, Marissa, \& Vera Diyanty. (2014). Pengaruh struktur kepemilikan dan mekanisme corporate governance terhadap tingkat pengungkapan laporan keberlanjutan. Simposium Nasional Akuntansi (SNA) XVII, Universitas Mataram-Lombok. 
Raja, D.R., R. Anugerah, Desmiyawati, \& Kamaliah. (2014). Aktivitas manajemen laba: analisis peran komite audit, kepemilikan institusional, persentase saham publik, dan leverage. Simposium Nasional Akuntansi (SNA) XVII, Universitas Mataram Lombok.

Rajpal, Hanish. (2012). Independent Directors and Earnings Management - Evidence from India. International Journal of Accounting and Financial Management Research, 2 (4), 9-24.

Richardson, Grant, Bei Wang, \& Xinmin Zhang. (2016). Ownership structure and corporate tax avoidance: Evidence from publicly listed private firms in China. Journal of Contemporary Accounting \& Economics, 12 (2), 141 - 158.

Tang, Tanya, \& Michael Firth. (2012). Earnings persistence and stock market reactions to the different information in book-tax differences: Evidence from China. The International Journal of Accounting, 47 (3), 369 - 397.

Waluyo. (2017). The effect of good corporate governance on tax avoidance: Empirical study of the Indonesian banking company. The Accounting Journal of BINANIAGA, 2 (2), $1-10$.

Widuri, Retnaningtyas, Winnie Wijaya, Jessica Effendi, \& Elvina Cikita. (2019). The effect of good corporate governance on tax avoidance of listed companies in Indonesian Stock Exchange in 2015 - 2017. Journal of Economics and Business, 2 (1), 120 - 126. 